\title{
Autumn olive (Elaeagnus umbellata Thunb.) berry reduces fasting and postprandial glucose levels in mice
}

\author{
Jung-In Kim ${ }^{\S}$, Hee-Jin Baek, Do-Won Han and Jeong-A Yun \\ Department of Smart Food and Drug, School of Bio Nano Information Technology, Inje University, 197 Inje-ro, Gimhae, Gyeongnam 50834, Korea
}

BACKGROUND/OBJECTIVES: Fasting and postprandial hyperglycemia should be controlled to avoid complications of diabetes mellitus. This study investigated the effects of autumn olive (Elaeagnus umbellata Thunb.) berry (AOB) on fasting and postprandial hyperglycemia in mice.

MATERIALS/METHODS: In vitro a-glucosidase inhibitory effect of AOB was determined. Maltose solution (2 g/ $\mathrm{kg})$ with and without $A O B$ extract at $500 \mathrm{mg} / \mathrm{kg}$ or acarbose at $50 \mathrm{mg} / \mathrm{kg}$ was orally administered to normal mice after overnight fasting and glucose levels were measured. To study the effects of chronic consumption of $A O B, \mathrm{db} / \mathrm{db}$ mice received the basal diet or a diet containing $\mathrm{AOB}$ extract at $0.4 \%$ or $0.8 \%$, or acarbose at $0.04 \%$ for 7 weeks. Blood glycated hemoglobin and serum glucose and insulin levels were measured. Expression of adiponectin protein in epididymal white adipose tissue was determined by Western blotting.

RESULTS: In vitro inhibitory effect of $A O B$ extract on a-glucosidase was $92 \%$ as strong as that of acarbose. The AOB extract $(500 \mathrm{mg} / \mathrm{kg})$ or acarbose $(50 \mathrm{mg} / \mathrm{kg})$ significantly suppressed the postprandial rise of blood glucose after maltose challenge and the area under the glycemic response curve in normal mice. The AOB extract at $0.4 \%$ or $0.8 \%$ of diet or acarbose at $0.04 \%$ of diet significantly lowered levels of serum glucose and blood glycated hemoglobin and homeostasis model assessment for insulin resistance values in $\mathrm{db} / \mathrm{db}$ mice. The expression of adiponectin protein in adipose tissue was significantly elevated by the consumption of $\mathrm{AOB}$ at $0.8 \%$ of diet.

CONCLUSIONS: Autumn olive (E. umbellata Thunb.) berry may reduce postprandial hyperglycemia by inhibiting a-glucosidase in normal mice. Chronic consumption of AOB may alleviate fasting hyperglycemia in $\mathrm{db} / \mathrm{db}$ mice partly by inhibiting $\mathrm{a}$-glucosidase and upregulating adiponectin expression.

Nutrition Research and Practice 2019;13(1):11-16; https://doi.org/10.4162/nrp.2019.13.1.11; pISSN 1976-1457 elSSN 2005-6168

Keywords: Elaeagnus umbellata, a-glucosidase, glycated hemoglobin, adiponectin, diabetes mellitus

\section{INTRODUCTION}

Fasting and postprandial hyperglycemia of diabetes mellitus can cause diabetic complications such as cardiovascular disease, nephropathy, and neuropathy [1]. Type 2 diabetes, the most common type of diabetes [2], is caused by insulin resistance and relative insulin insufficiency [3]. Type 2 diabetics have 2-10 times greater risk for mortality due to macro- and microvascular diseases compared to non-diabetic population [4,5]. Because postprandial hyperglycemia is strongly associated with increased risk of cardiovascular complications of type 2 diabetes, it is important to avoid both fasting and postprandial hyperglycemia in type 2 diabetes [6]. Hyperglycemia also increases oxidative stress [7], which is associated with development and progression of cardiovascular diseases related to diabetes mellitus [8].

Postprandial hyperglycemia in diabetes can be controlled by impairing the digestion of dietary carbohydrates by inhibiting a-glucosidases [9]. The a-glucosidase inhibitor acarbose has been used as an oral hypoglycemic agent, but its gastrointestinal side effects include flatulence, abdominal discomfort, bloating, and diarrhea [10]. Therefore, much effort has been directed to the search for safe and effective a-glucosidase inhibitors from natural sources, including edible plants [11,12].

Autumn olive (Elaeagnus umbellata Thunb.) is a plant in the family Elaeagnaceae that is native to East Asia [13]. This plant produces small edible deep-red berries with a sweet-tart taste. These are consumed in Korea, China, and Japan [13]. Autumn olive berry $(A O B)$ is good source of vitamin $C$ and vitamin $E$ $[13,14]$. AOB is a rich source of lycopene [15] and has strong antioxidant activity $[14,16]$. Therefore, AOB could be effective in reducing oxidative stress in diabetes mellitus. However, the effects of $A O B$ on a-glucosidase are not clear. $A O B$ is also a good source of proanthocyanidins [13]. The proanthocyanidins in a grape seed extract improve insulin sensitivity by inducing

\footnotetext{
This research was supported by Basic Science Research Program through the National Research Foundation of Korea (NRF) funded by the Ministry of Education (2016R1D1A3B03930584).

${ }^{\S}$ Corresponding Author: Jung-In Kim, Tel. 82-55-320-3236, Fax. 82-55-321-0691, Email. fdsnkiji@inje.ac.kr

Received: July 16, 2018, Revised: August 28, 2018, Accepted: October 25, 2018

This is an Open Access article distributed under the terms of the Creative Commons Attribution Non-Commercial License (http://creativecommons.org/licenses/by-nc/3.0/) which permits unrestricted non-commercial use, distribution, and reproduction in any medium, provided the original work is properly cited.
} 
adiponectin mRNA expression in rats with high-fructose diet-induced insulin resistance [17]. The goal of this study was to investigate the anti-diabetic potential of $A O B$. The $a$ -glucosidase inhibitory activity of $A O B$ was assessed in vitro. The effect of $A O B$ on postprandial glucose excursion was also examined in normal mice. In addition, we studied the effect of chronic treatment with $A O B$ on fasting blood glucose levels, insulin resistance, and adiponectin protein expression in type 2 diabetic mouse model.

\section{MATERIALS AND METHODS}

\section{Preparation of $A O B$ extract}

Autumn olive berries were purchased from a local market in Hapcheon, Korea. The berries were lyophilized, milled, and then extracted by shaking with ethanol $(1: 10 \mathrm{~m} / \mathrm{v})$ for $12 \mathrm{~h}$ twice. After the extract was filtered, ethanol in the extract was removed with a rotary evaporator at $50^{\circ} \mathrm{C}$ (EYELA, Tokyo, Japan).

\section{Enzyme inhibition assay}

The chromogenic method was used to determine in vitro a -glucosidase inhibitory activity of AOB [18]. The sample solution ( $5 \mathrm{mg} / \mathrm{mL}$ ) was prepared by dissolving $A O B$ extract in dimethyl sulfoxide (DMSO; Sigma Chemical, St. Louis, MO, USA). Yeast a-glucosidase (0.7 U, Sigma Chemical) was dissolved in $100 \mathrm{mM}$ phosphate buffer ( $\mathrm{pH}$ 7.0) which contains bovine serum albumin $(2 \mathrm{mg} / \mathrm{mL})$ and $\mathrm{NaN}_{3}(0.2 \mathrm{mg} / \mathrm{mL})$ to prepare the enzyme solution. $p$-Nitrophenyl-a-D-glucopyranoside ( $p$-NGP; 5 $\mathrm{mM}$, Sigma Chemical) was dissolved in $100 \mathrm{mM}$ phosphate buffer ( $\mathrm{pH}$ 7.0) to prepare the substrate solution. The sample solution $(10 \mu \mathrm{L})$ and the enzyme solution $(50 \mu \mathrm{L})$ were mixed and the absorbance was recorded at $405 \mathrm{~nm}$ by a microplate reader (MQX200R, BioTek, Winooski, VT, USA). After incubation at room temperature for $5 \mathrm{~min}$, the substrate solution $(50 \mu \mathrm{L})$ was added to the mixture. The reaction mixture was further incubated for $5 \mathrm{~min}$, and the absorbance was recorded at 405 $\mathrm{nm}$. Acarbose (5 mg/mL, Bayer Korea, Seoul, Korea) was used as a positive control. The assays were done in triplicate.

\section{Measuring postprandial glycemic excursions in mice}

A total of 21 male C57BL/6J mice (age, six weeks, Bio Genomics, Seoul, Korea) were separately housed under controlled temperature $\left(19-23^{\circ} \mathrm{C}\right)$ and humidity $(40-60 \%)$ and a $12 \mathrm{~h}$ light/12 $\mathrm{h}$ dark cycle. The animals had ad libitum access to standard rodent pellets (Purina, Seongnam, Korea) and tap water. Mice weighing 23-26 g were randomly divided into three groups. The control group was administered maltose orally ( $2 \mathrm{~g} / \mathrm{kg}$ body weight) after an overnight fast. The $A O B$ group was treated with maltose $(2 \mathrm{~g} / \mathrm{kg}$ ) and $500 \mathrm{mg} / \mathrm{kg}$ AOB extract. The acarbose group was treated with maltose $(2 \mathrm{~g} / \mathrm{kg})$ and $50 \mathrm{mg} / \mathrm{kg}$ acarbose. Blood samples were acquired from the tip of tail vein 0-120 min after maltose administration. Glucose levels were measured using the Glucotrend glucometer (Roche Diagnostics, Lewes, UK). The areas under the curves (AUCs) for glucose were calculated.

\section{Measuring fasting blood glucose levels in $\mathrm{db} / \mathrm{db}$ mice}

A total of 28 male C57BL/KsJ-db/db mice (age, six weeks) were obtained from the Korea Research Institute of Bioscience and
Biotechnology (Ochang, Korea). After 1 week of acclimatization, the mice were assigned to four groups. The control group was fed the basal diet, AIN-93G diet [19] ad libitum for 7 weeks. The low (LAOB) and high (HAOB) autumn olive berry groups received AIN-93G diet containing $0.4 \%$ and $0.8 \%$ AOB extract, respectively, which replaced cornstarch. Based on a preliminary study, it was assumed that the food intake and average of initial and final body weights of the mice would be $4 \mathrm{~g} /$ day and 30 $\mathrm{g}$, respectively. The diets containing $0.4 \%$ and $0.8 \% \mathrm{AOB}$ extract were expected to provide approximately 500 and $1,000 \mathrm{mg} / \mathrm{kg}$ body weight of $A O B$ extract daily, based on assumed food intake and average body weight. The acarbose group received the diet containing $0.04 \%$ acarbose, which replaced cornstarch. The diet containing $0.04 \%$ acarbose was expected to provide approximately $50 \mathrm{mg} / \mathrm{kg}$ body weight of acarbose daily. After the mice were fasted overnight (12 h), they were sacrificed by cardiac puncture. Blood samples were collected and serum was obtained after centrifuging the blood at $1,500 \mathrm{~g}$ for $15 \mathrm{~min}$. Epididymal white adipose tissue (WAT) was excised. Serum and the WAT were stored at $-70^{\circ} \mathrm{C}$ for further analyses.

Blood glycated hemoglobin $\left(\mathrm{HbA}_{1 \mathrm{C}}\right)$ was measured with a chromatographic method using a commercially available assay kit (BioSystems, Barcelona, Spain). Serum glucose was determined using a commercial enzymatic assay kit (Yeongdong, Seoul, Korea). Serum insulin was assayed using a commercial enzymelinked immunosorbent assay (ELISA) kit (Mercodia, Uppsala, Sweden). Homeostasis model assessment for insulin resistance (HOMA-IR) was defined as [Fasting insulin $(\mu \mathrm{U} / \mathrm{mL}) \times$ fasting glucose $(\mathrm{mmol} / \mathrm{L}) / 22.5]$ [20].

To determine the expression of adiponectin using Western blotting, epididymal WAT samples were homogenized in protein extraction solution (PRO-PREP ${ }^{\mathrm{TM}}$, Intron Biotechnology, Korea), and then centrifuged at $13,000 \mathrm{~g}$ for $30 \mathrm{~min}$. Total protein of the supernatants were measured using a bicinchoninic acid assay (Thermo Fisher Scientific, Rockford, IL, USA) with bovine serum protein as the reference protein. Protein sample $(40 \mu \mathrm{g})$ was separated using SDS-polyacrylamide gels and then transferred onto a polyvinylidene difluoride membranes (Bio-Rad Laboratories, Richmond, CA, USA) for 30 min. Following blocking using $5 \%$ skim milk for $12 \mathrm{~h}$ at $4^{\circ} \mathrm{C}$, the membranes were incubated with 1:1,000 diluted anti-adiponectin antibody (Cell Signaling Technology, Danvers, MA, USA) and anti- $\beta$-actin antibody (Cell Signaling Technology) for $24 \mathrm{~h}$ at $4^{\circ} \mathrm{C}$. The membranes were incubated with 1:1,000 diluted horseradish peroxide (HRP)-linked anti-rabbit immunoglobulin G (IgG) secondary antibody (Cell Signaling Technology) for $3 \mathrm{~h}$ at $4^{\circ} \mathrm{C}$. The blots were exposed to enhanced chemiluminescence $(\mathrm{ECL})$ reagent (GE Healthcare, Chalfont, St. Giles, UK). The protein expression was normalized to $\beta$-actin. All of the animal protocols used in this study were approved by the Animal Resource Center at Inje University, Korea (Approval n. 2016-020 and 2016-021).

\section{Statistical analysis}

The data are presented as the Mean \pm standard error (SE). One-way analysis of variance with a post hoc Tukey test were used to determine significant differences among the groups ( $P$ $<0.05)$. The statistical analyses were performed with SAS ver. 9.4 (SAS Institute, Cary, NC, USA). 


\section{RESULTS}

In vitro inhibitory effect of $A O B$ on a-glucosidase

The extraction yield of the ethanol extract of $A O B$ was $36.7 \%$. The AOB extract showed $42.1 \%$ inhibitory activity against yeast a-glucosidase, compared to $45.8 \%$ inhibition by acarbose, the positive control, in vitro (Fig. 1).

Suppression of postprandial blood glucose in normal mice by $A O B$

Fig. 2 shows the effects of the AOB extract on postprandial blood glucose levels 0-120 min after maltose loading and the AUCs for the glucose responses in normal mice. The mice treated with the AOB extract at $500 \mathrm{mg} / \mathrm{kg}$ showed significantly lowered incremental blood glucose levels $30(P<0.01)$ and 60 $(P<0.05)$ min after maltose administration $(2 \mathrm{~g} / \mathrm{kg})$ compared with the mice administered maltose. Administration of acarbose $(50 \mathrm{mg} / \mathrm{kg})$ resulted in significant reduction in the incremental blood glucose at 30, 60 (both $P<0.01)$, and $90(P<0.05) \mathrm{min}$ compared with the control group. The incremental blood glucose level at $90 \mathrm{~min}$ in mice administered maltose with $\mathrm{AOB}$ was not significantly different from those in mice administered maltose alone or maltose with acarbose. The AUCs in the AOB $(3,758 \pm 482 \mathrm{mg} \cdot \mathrm{min} / \mathrm{dL}, P<0.05)$ and acarbose $(2,491 \pm 221$ $\mathrm{mg} \cdot \mathrm{min} / \mathrm{dL}, P<0.01)$ groups were lower than those in the control group $(5,563 \pm 620 \mathrm{mg} \cdot \mathrm{min} / \mathrm{dL})$. The AUCs of the AOB and acarbose groups did not differ significantly.

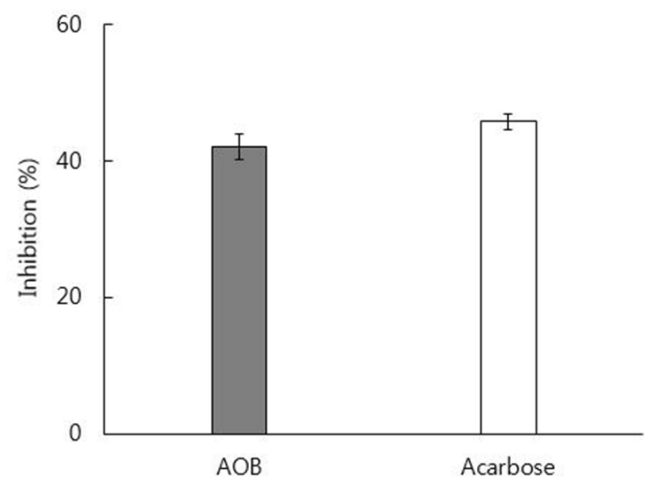

Fig. 1. Inhibitory activity of autumn olive berry against yeast a-glucosidase. The inhibitory activities of the ethanol extract of autumn olive berry (AOB) and acarbose were measured at a concentration of $5 \mathrm{mg} / \mathrm{mL}$. Values represent Means $\pm S E$ of triplicate measurements.
(A)

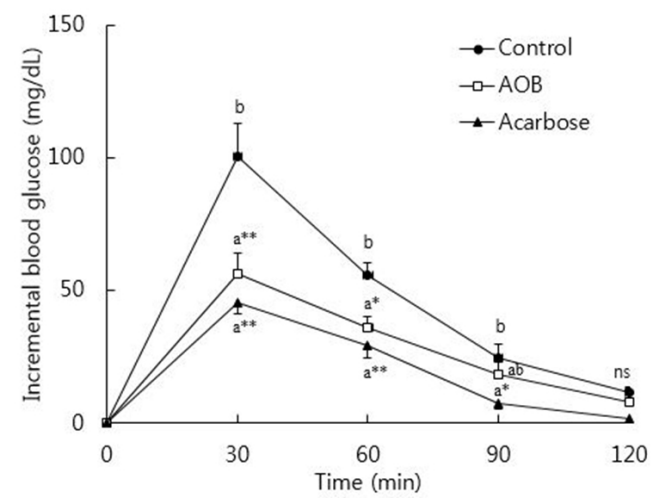

(B)

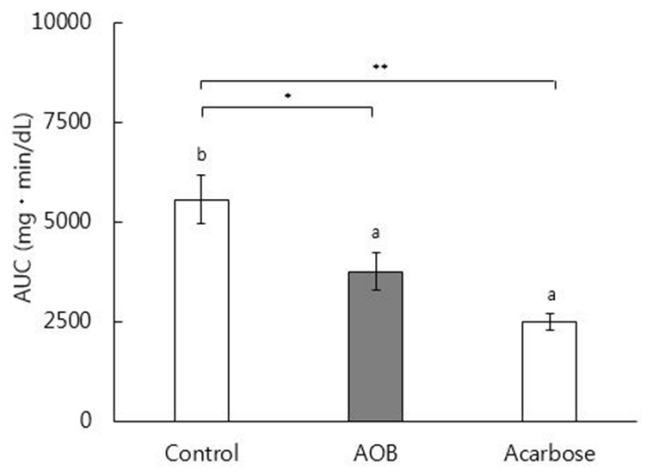

Fig. 2. Increase in blood glucose after administration of extract of autumn olive berry in normal mice. (A) Incremental blood glucose levels. (B) Areas under the glucose response curves. Control group $(\bullet)$ : Maltose $(2 \mathrm{~g} / \mathrm{kg})$ was administered orally to normal mice after an overnight fast. AOB group $(\square)$ : Maltose $(2 \mathrm{~g} / \mathrm{kg})$ with extract of autumn olive berry $(500 \mathrm{mg} / \mathrm{kg})$ was administered to mice after an overnight fast. Acarbose group $(\boldsymbol{\Lambda})$ : Maltose $(2 \mathrm{~g} / \mathrm{kg})$ with acarbose $(50 \mathrm{mg} / \mathrm{kg})$ was administered to mice after an overnight fast. Values represent Means $\pm S E(n=7)$. (A) Means that do not share a common letter are significantly different at $P<0.05\left(^{*}\right)$ or $P<0.01\left(^{(\star}\right)$. (B) Bars that do not share a common letter are significantly different at $P<0.05\left(^{(*)}\right.$ or $P<0.01\left(^{(*)}\right.$.

Alleviation of fasting hyperglycemia in $d b / d b$ mice by $A O B$

Body weight, weight gain, and feed efficiency ratio were not significantly affected by the consumption of the AOB extract ( $0.4 \%$ and $0.8 \% \mathrm{wt} / \mathrm{wt}$ of diet for LAOB and HAOB groups, respectively) or acarbose $(0.04 \% \mathrm{wt} / \mathrm{wt}$ of diet) in the $\mathrm{db} / \mathrm{db}$ mice (Table 1). The serum levels of glucose were significantly lower in the $\angle A O B, H A O B$, and acarbose groups than those in the control group $(P<0.05$, Table 2$)$. The consumption of $L A O B$, $\mathrm{HAOB}$, or acarbose significantly reduced the blood $\mathrm{HbA}_{1 \mathrm{C}}$ compared to the controls. The serum levels of insulin in the four groups did not differ significantly. In comparison with the

Table 1. Body weight, food intake, and feed efficiency ratio of $\mathrm{db} / \mathrm{db}$ mice

\begin{tabular}{|c|c|c|c|c|}
\hline Group ${ }^{1)}$ & Control & LAOB & $\mathrm{HAOB}$ & Acarbose \\
\hline Initial body weight (g) & $22.8 \pm 0.6^{\mathrm{NS}}$ & $23.0 \pm 0.7$ & $22.3 \pm 0.6$ & $22.5 \pm 0.5$ \\
\hline Final body weight (g) & $41.9 \pm 1.1^{\mathrm{NS}}$ & $40.0 \pm 1.3$ & $39.1 \pm 1.3$ & $39.3 \pm 1.1$ \\
\hline Weight gain (mg/day) & $389.2 \pm 12.2^{\mathrm{NS}}$ & $346.5 \pm 15.5$ & $342.4 \pm 24.3$ & $343.0 \pm 13.7$ \\
\hline Food intake (g/day) & $4.2 \pm 0.2^{\mathrm{NS}}$ & $4.0 \pm 0.1$ & $3.9 \pm 0.1$ & $3.9 \pm 0.1$ \\
\hline FER $(\%)^{2)}$ & $9.41 \pm 0.49^{\mathrm{NS}}$ & $8.67 \pm 0.32$ & $8.72 \pm 0.56$ & $8.75 \pm 0.27$ \\
\hline
\end{tabular}

${ }^{1)}$ Control, mice fed AIN-93G diet; LAOB, mice fed diet containing $0.4 \%$ autumn olive berry extract; HAOB, mice fed diet containing $0.8 \%$ autumn olive berry extract; Acarbose, mice fed diet containing $0.04 \%$ acarbose

2) Feed efficiency ratio $($ FER, \%) $=($ Body weight gain $(g /$ day $) /$ food intake $(g /$ day $)) \times 100$

3) Values are Means \pm SE $(n=7)$.

4) NS, not significant 
Table 2. Blood glycated hemoglobin, serum glucose, insulin, and HOMA-IR value of $\mathrm{db} / \mathrm{db}$ mice

\begin{tabular}{|c|c|c|c|c|}
\hline Group $^{11}$ & Control & LAOB & HAOB & Acarbose \\
\hline Blood glycated hemoglobin (\%) & $8.00 \pm 0.16^{\mathrm{b3})}$ & $7.23 \pm 0.17^{\mathrm{a}}$ & $6.97 \pm 0.21^{\mathrm{a}}$ & $6.83 \pm 0.22^{\mathrm{a}}$ \\
\hline Serum glucose $(\mathrm{mg} / \mathrm{dL})$ & $446.3 \pm 17.6^{b}$ & $365.8 \pm 16.6^{\mathrm{a}}$ & $326.6 \pm 18.9^{a}$ & $315.4 \pm 13.0^{\mathrm{a}}$ \\
\hline Serum insulin $(\mu \mathrm{U} / \mathrm{mL})$ & $82.3 \pm 4.3^{\mathrm{NS} 4)}$ & $74.5 \pm 4.7$ & $70.9 \pm 4.6$ & $78.2 \pm 4.5$ \\
\hline HOMA-IR ${ }^{2)}$ & $90.2 \pm 4.9^{b}$ & $66.7 \pm 3.7^{\mathrm{a}}$ & $56.9 \pm 4.6^{\mathrm{a}}$ & $60.8 \pm 4.0^{\mathrm{a}}$ \\
\hline
\end{tabular}

1) Groups are the same as in Table 1.

2) Homeostasis model assessment for insulin resistance $(\mathrm{HOMA}-\mathrm{IR})=$ Fasting glucose $(\mathrm{mmol} / \mathrm{L}) \times$ fasting insulin $(\mu \mathrm{U} / \mathrm{mL}) / 22.5$

3) Values are Means \pm SE $(n=7)$. Means in the same row not sharing a common letter are significantly different at $P<0.05$

4) NS, not significant

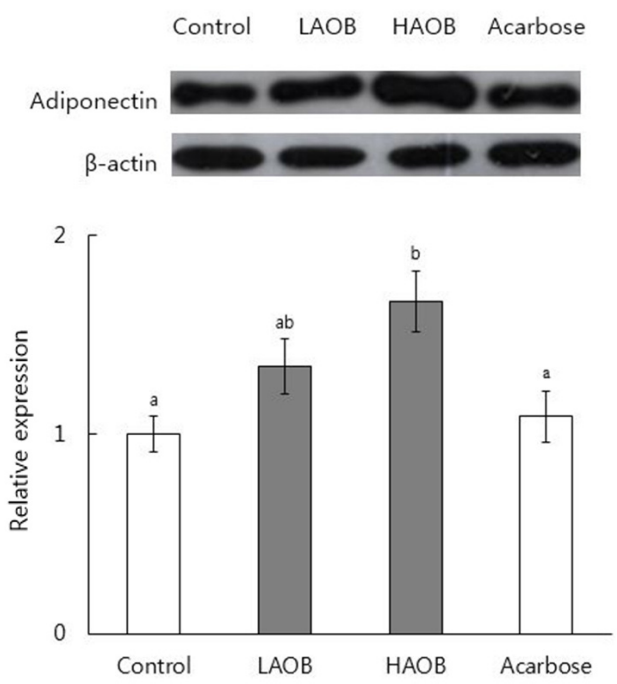

Fig. 3. Expression of adiponectin protein in the epididymal adipose tissue in $\mathrm{db} / \mathrm{db}$ mice measured by Western blotting. Groups are the same as in Table 1. A representative image of the experiments is shown in the upper panel. The lower panel shows the relative expression normalized to the protein expression levels of $\beta$-actin. Values represent Means \pm SE $(n=7)$. Bars that do not share a common letter are significantly different at $P<0,05$.

mice fed the basal diet, the HOMA-IR values of the LAOB, HAOB, and acarbose groups were significantly reduced. Blood $\mathrm{HbA}_{1 \mathrm{C}}$, glucose, and HOMA-IR values did not differ significantly among the $L A O B, H A O B$, and acarbose groups. The consumption of HAOB significantly increased the expression of adiponectin protein in epididymal WAT compared to the control and acarbose groups $(P<0.05$, Fig. 3). There was a tendency for LAOB to elevate adiponectin expression compared with the control and acarbose groups.

\section{DISCUSSION}

a-Glucosidase is essential for the digestion of carbohydrates before monosaccharide absorption in the small intestine and inhibition of this enzyme can alleviate postprandial hyperglycemia [9]. The in vitro study demonstrated that a-glucosidase inhibitory activity of $A O B$ extract was $92 \%$ as strong as that of acarbose (Fig. 1). a-Glucosidase inhibitors have shown to flatten postprandial increase in blood glucose in both normal mice and mice with diabetes [21-23]. In this study we compared the effect of $\mathrm{AOB}$ and acarbose on postprandial hyperglycemia after maltose loading in normal mice. The administration of $A O B$ extract at $500 \mathrm{mg} / \mathrm{kg}$ was effective at reducing the postprandial blood glucose level and AUC of the glucose response and these effects of $A O B$ were comparable to acarbose administered at $50 \mathrm{mg} / \mathrm{kg}$ in the mice (Fig. 2). These results suggest that AOB shows a -glucosidase inhibitory activity in vivo. Postprandial hyperglycemia is seen earlier than fasting hyperglycemia as individuals progress toward type 2 diabetes [24]. Postprandial hyperglycemia is a crucial risk factor for cardiovascular complications among type 2 diabetics [6]. Therefore, flattening the glucose response after a meal with $A O B$ could be beneficial in the prevention of type 2 diabetes and type 2 diabetes-associated cardiovascular complications.

a-Glucosidase inhibitory activity and polyphenolic content of plants are positively correlated [12]. Plant polyphenols, particularly flavonoids, phenolic acids, and tannins, are beneficial in controlling blood glucose by inhibiting a-glucosidase [25]. It has been reported that $A O B$ is high in total phenolic content (190 $-275 \mathrm{mg} / 100 \mathrm{~g}$ fresh weight) [13]. Polyphenolic compounds in AOB could contribute to a-glucosidase inhibition. It is necessary to find the active components in $A O B$ inhibiting a-glucosidase in further studies.

The effects of different doses of $A O B$ extract on fasting hyperglycemia were examined in $\mathrm{db} / \mathrm{db}$ mice, which are leptin-deficient and develop obesity, hyperglycemia, and insulin resistance, characteristics of type 2 diabetes [26]. The $\mathrm{db} / \mathrm{db}$ mice given the $A O B$ extract at $0.4 \%$ (LAOB) and $0.8 \%$ (HAOB) of the diet for 7 weeks had lower serum levels of glucose in a dose-dependent manner; $\angle A O B$ and HAOB reduced glucose levels by $18 \%$ and $27 \%$, respectively, compared to the control. These hypoglycemic effects of $\angle A O B$ and HAOB were comparable to those of acarbose given at $0.04 \%$ of the diet. The average daily intake of $A O B$ extract by the $L A O B$ and $H A O B$ groups was calculated to be $502 \pm 18$ and 1,009 $\pm 19 \mathrm{mg} / \mathrm{kg}$ body weight, respectively, whereas the daily intake of acarbose by the acarbose group was $50 \pm 2 \mathrm{mg} / \mathrm{kg}$ body weight. The mice received $L A O B, H A O B$, or acarbose showed lowered HOMA-IR, a surrogate parameter of insulin resistance, compared with the basal diet-fed mice. Clinical trials have confirmed that acarbose monotherapy lowers the fasting blood levels of glucose in patients with type 2 diabetes [27-29]. Acarbose lowers postprandial hyperglycemia and hyperinsulinemia, thereby reducing the stimulation of insulin synthesis and insulin secretion, contributing to improved insulin sensitivity, which leads to overall glycemic control [30]. The consumption of HAOB increased the expression of adiponectin protein in this study. Adiponectin is a hormone that is expressed in adipose tissues, and adiponectin sensitizes insulin action [31]. Therefore, AOB could improve insulin sensitivity partly by inhibiting a-glucosidase and increasing the 
expression of adiponectin. HOMA-IR value of HAOB group tended to be decreased compared with the acarbose group, although the difference was not significant. Diabetes increases inflammation which contributes to development and aggravation of diabetic complications [32,33]. Adiponectin has been reported to be anti-inflammatory factor which reduces pro-inflammatory cytokine levels [34]. Thus, further study to determine the anti-inflammatory effect of HAOB in diabetes could be worthwhile. The proanthocyanidin-rich extract of grape seed induces adiponectin mRNA expression and the expression of Akt protein, an insulin signaling pathway-related factor, in rats with diet-induced insulin resistance [17]. In our study, the proanthocyanidins in $A O B$ might have helped to alleviate insulin resistance by inducing adiponectin expression.

The consumption of $\angle A O B$ or $H A O B$ significantly reduced $\mathrm{HbA}_{1 \mathrm{c}}$. Both fasting and postprandial blood levels of glucose are important for determining $\mathrm{HbA}_{1 c}$ [35]. $\mathrm{HbA}_{1 c}$ levels are strongly related to the incidence and severity of diabetic complications, including cardiovascular complications, the most common reason for the premature death of type 2 diabetics $[36,37]$. Consequently, reducing fasting and postprandial hyperglycemia by $A O B$ could be beneficial in prevention of cardiovascular complications.

In conclusion, AOB reduced postprandial hyperglycemia by inhibiting a-glucosidase in normal mice. The chronic consumption of $A O B$ alleviated fasting hyperglycemia and improved insulin sensitivity partly by inhibiting a-glucosidase and upregulating adiponectin expression in $\mathrm{db} / \mathrm{db}$ mice. Therefore, $A O B$ could be a useful hypoglycemic agent.

\section{CONFLICT OF INTEREST}

The authors declare no potential conflicts of interests.

\section{ORCID}

Jung-In Kim: https://orcid.org/0000-0002-3829-2665

Hee-Jin Baek: https://orcid.org/0000-0003-0606-4374

Do-Won Han: https://orcid.org/0000-0003-2214-9423

Jeong-A Yun: https://orcid.org/0000-0001-8844-2628

\section{REFERENCES}

1. Zatalia SR, Sanusi H. The role of antioxidants in the pathophysiology, complications, and management of diabetes mellitus. Acta Med Indones 2013;45:141-7.

2. Cheng D. Prevalence, predisposition and prevention of type II diabetes. Nutr Metab (Lond) 2005;2:29.

3. King $H$, Aubert RE, Herman WH. Global burden of diabetes, 1995-2025: prevalence, numerical estimates, and projections. Diabetes Care 1998;21:1414-31.

4. Stamler J, Vaccaro O, Neaton JD, Wentworth D. Diabetes, other risk factors, and 12-yr cardiovascular mortality for men screened in the Multiple Risk Factor Intervention Trial. Diabetes Care 1993;16: 434-44.

5. Manson JE, Colditz GA, Stampfer MJ, Willett WC, Krolewski AS, Rosner B, Arky RA, Speizer FE, Hennekens CH. A prospective study of maturity-onset diabetes mellitus and risk of coronary heart disease and stroke in women. Arch Intern Med 1991;151:1141-7.

6. Bonora E, Muggeo M. Postprandial blood glucose as a risk factor for cardiovascular disease in type II diabetes: the epidemiological evidence. Diabetologia 2001;44:2107-14.

7. Brownlee M. Biochemistry and molecular cell biology of diabetic complications. Nature 2001;414:813-20.

8. Ceriello A. Postprandial hyperglycemia and diabetes complications: is it time to treat? Diabetes 2005;54:1-7.

9. Standl E, Baumgartl HJ, Füchtenbusch M, Stemplinger J. Effect of acarbose on additional insulin therapy in type 2 diabetic patients with late failure of sulphonylurea therapy. Diabetes Obes Metab 1999;1:215-20.

10. Bressler R, Johnson D. New pharmacological approaches to therapy of NIDDM. Diabetes Care 1992;15:792-805.

11. Kumar S, Narwal S, Kumar V, Prakash O. a-Glucosidase inhibitors from plants: a natural approach to treat diabetes. Pharmacogn Rev 2011;5:19-29.

12. Mai TT, Thu NN, Tien PG, Van Chuyen N. Alpha-glucosidase inhibitory and antioxidant activities of Vietnamese edible plants and their relationships with polyphenol contents. J Nutr Sci Vitaminol (Tokyo) 2007;53:267-76.

13. Pei R, Yu M, Bruno R, Bolling BW. Phenolic and tocopherol content of autumn olive (Elaeagnus umbellate) berries. J Funct Foods 2015;16:305-14.

14. Khattak KF. Free radical scavenging activity, phytochemical composition and nutrient analysis of Elaeagnus umbellata berry. J Med Plants Res 2012;6:5196-203.

15. Fordham IM, Clevidence BA, Wiley ER, Zimmerman RH. Fruit of autumn olive: a rich source of lycopene. HortScience 2001;36: 1136-7.

16. Wang SY, Fordham IM. Differences in chemical composition and antioxidant capacity among different genotypes of autumn olive (Elaeagnus umbellate Thunb.). Food Technol Biotechnol 2007;45: 402-9.

17. Meeprom A, Sompong W, Suwannaphet W, Yibchok-anun S, Adisakwattana S. Grape seed extract supplementation prevents high-fructose diet-induced insulin resistance in rats by improving insulin and adiponectin signalling pathways. Br J Nutr 2011;106: 1173-81.

18. Watanabe J, Kawabata J, Kurihara H, Niki R. Isolation and identification of a-glucosidase inhibitors from tochu-cha (Eucommia ulmoides). Biosci Biotechnol Biochem 1997;61:177-8.

19. Reeves PG, Nielsen FH, Fahey GC Jr. AIN-93 purified diets for laboratory rodents: final report of the American Institute of Nutrition ad hoc writing committee on the reformulation of the AIN-76A rodent diet. J Nutr 1993;123:1939-51.

20. Haffner SM, Miettinen $H$, Stern MP. The homeostasis model in the San Antonio Heart Study. Diabetes Care 1997;20:1087-92.

21. Heo SJ, Hwang JY, Choi JI, Han JS, Kim HJ, Jeon YJ. Diphlorethohydroxycarmalol isolated from Ishige okamurae, a brown algae, a potent a-glucosidase and a-amylase inhibitor, alleviates postprandial hyperglycemia in diabetic mice. Eur J Pharmacol 2009;615:252-6.

22. Karato M, Yamaguchi K, Takei S, Kino T, Yazawa K. Inhibitory effects of pasuchaca (Geranium dielsiaum) extract on a-glucosidase in mouse. Biosci Biotechnol Biochem 2006;70:1482-4.

23. Miura $T$, Koide $T$, Ohichi R, Kako M, Usami M, Ishihara E, Yasuda $\mathrm{N}$, Ishida $\mathrm{H}$, Seino $\mathrm{Y}$, Tanigawa K. Effect of acarbose (a-glucosidase inhibitor) on disaccharase activity in small intestine in KK-Ay and 
ddY mice. J Nutr Sci Vitaminol (Tokyo) 1998;44:371-9.

24. Gerich JE. Clinical significance, pathogenesis, and management of postprandial hyperglycemia. Arch Intern Med 2003;163:1306-16.

25. Bahadoran Z, Mirmiran P, Azizi F. Dietary polyphenols as potential nutraceuticals in management of diabetes: a review. J Diabetes Metab Disord 2013;12:43.

26. Srinivasan K, Ramarao P. Animal models in type 2 diabetes research: an overview. Indian J Med Res 2007;125:451-72.

27. Chiasson JL, Josse RG, Hunt JA, Palmason C, Rodger NW, Ross SA, Ryan EA, Tan MH, Wolever TM. The efficacy of acarbose in the treatment of patients with non-insulin-dependent diabetes mellitus. A multicenter controlled clinical trial. Ann Intern Med 1994;121: 928-35.

28. Holman RR, Cull CA, Turner RC. A randomized double-blind trial of acarbose in type 2 diabetes shows improved glycemic control over 3 years (U.K. Prospective Diabetes Study 44). Diabetes Care 1999;22:960-4.

29. Meneilly GS, Ryan EA, Radziuk J, Lau DC, Yale JF, Morais J, Chiasson JL, Rabasa-Lhoret R, Maheux P, Tessier D, Wolever T, Josse RG, Elahi D. Effect of acarbose on insulin sensitivity in elderly patients with diabetes. Diabetes Care 2000;23:1162-7.

30. Breuer HW. Review of acarbose therapeutic strategies in the long-term treatment and in the prevention of type 2 diabetes. Int J Clin Pharmacol Ther 2003;41:421-40.
31. Nigro E, Scudiero O, Monaco ML, Palmieri A, Mazzarella $G$ Costagliola C, Bianco A, Daniele A. New insight into adiponectin role in obesity and obesity-related diseases. BioMed Res Int 2014;2014:658913.

32. Alexandraki KI, Piperi C, Ziakas PD, Apostolopoulos NV, Makrilakis K, Syriou V, Diamanti-Kandarakis E, Kaltsas G, Kalofoutis A. Cytokine secretion in long-standing diabetes mellitus type 1 and 2 : associations with low-grade systemic inflammation. J Clin Immunol 2008;28:314-21.

33. Navarro JF, Mora C. Role of inflammation in diabetic complications Nephrol Dial Transplant 2005;20:2601-4.

34. Polyzos SA, Kountouras J, Zavos C, Tsiaousi E. The role of adiponectin in the pathogenesis and treatment of non-alcoholic fatty liver disease. Diabetes Obes Metab 2010;12:365-83.

35. Monnier L, Colette C, Monnier L, Colette C. Contributions of fasting and postprandial glucose to hemoglobin A1c. Endocr Pract 2006;12 Suppl 1:42-6.

36. Knowler WC, Barrett-Connor E, Fowler SE, Hamman RF, Lachin JM Walker EA, Nathan DM; Diabetes Prevention Program Research Group. Reduction in the incidence of type 2 diabetes with lifestyle intervention or metformin. N Engl J Med 2002;346:393-403.

37. O'Keefe JH Jr, Miles JM, Harris WH, Moe RM, McCallister BD. Improving the adverse cardiovascular prognosis of type 2 diabetes. Mayo Clin Proc 1999;74:171-80. 